\title{
BASIL T. PARSONS-SMITH
}

Basil Thomas Parsons-Smith, Consulting Physician to the National Heart Hospital, died after a short illness at his home in Tadworth, Surrey, on September 3, 1954, at the age of 72.

He received his early education at Sir Roger Manword's Grammar School, Sandwich, and his medical training at St. Thomas's Hospital where he qualified in 1907 and, after holding the posts of casualty officer and house physician, obtained the M.D. (Lond.) in 1909. He served in France during the first World War, and for a time was in charge of the heart centre at Cayeux-sur-Mer. On demobilization he obtained the M.R.C.P. (Lond.), and became heart specialist to the Ministry of Pensions, and Assistant Physician to the Cardiac Department at St. Thomas's Hospital. He was elected F.R.C.P. (Lond.) in 1929.

He was appointed Physician to Outpatients at the National Heart Hospital in 1920 and became Physician to the Hospital in 1929, a position that he held for 18 years. He acted as Dean to its Postgraduate Medical School from 1923 until 1947 and helped in the arrangements for the new Institute of Cardiology. On his retirement from the staff in October 1947 he was elected a member of the Committee of Management of the Hospital and in July, 1948, became a member of the Board of Governors, the meetings of which he attended regularly up to July, 1954.

In 1914 he was awarded the Hunterian Medal for a dissertation on the intermittent pulse. He delivered the Hunterian Society Oration in 1934, the St. Cyres Lecture at the National Heart Hospital in 1936, and the Lumleian Lectures dealing with the subject of heart failure at the Royal College of Physicians in 1950. He was president of the Clinical Section of the Royal Society of Medicine from 1936 to 1938, and of the Hunterian Society in 1952 when his inaugural address dealt with the progress of cardiology. He was a founder member of the British Cardiac Society and of the London Cardiological Club, serving as secretary of the latter from the start in 1922 till 1950.

He was an ardent Freemason and held office in Grand Lodge. He liked a game of golf and excelled at cricket, playing for St. Thomas's XI when an undergraduate, and on the village greens of Winchelsea and Buxted between the two world wars. He was a keen gardener and his lawns like himself grew no tares. He found no fault in others for he was without guile himself. Basil Parsons-Smith walked gracefully through life, erect in posture and likewise in character. No one could have been kinder to his friends and to his patients who received from him, in addition to skilled medical care, that sympathetic understanding which gave them strength to endure their suffering the more easily in that he shared it with them. Indeed, he was a good doctor and loved his calling so that he continued in active consulting practice after his retirement from hospital work.

He will be missed sorely by his friends and how much more at his home, where he both gave and received such great happiness; in 1910 he had married Marguerite, the daughter of Sir David Burnett, former Lord Mayor of London, and it is to her in her great grief, to their son who follows him in the profession, and to their daughter, that we extend our deep sympathy in their irreparable loss.

WILLIAM EVANS 


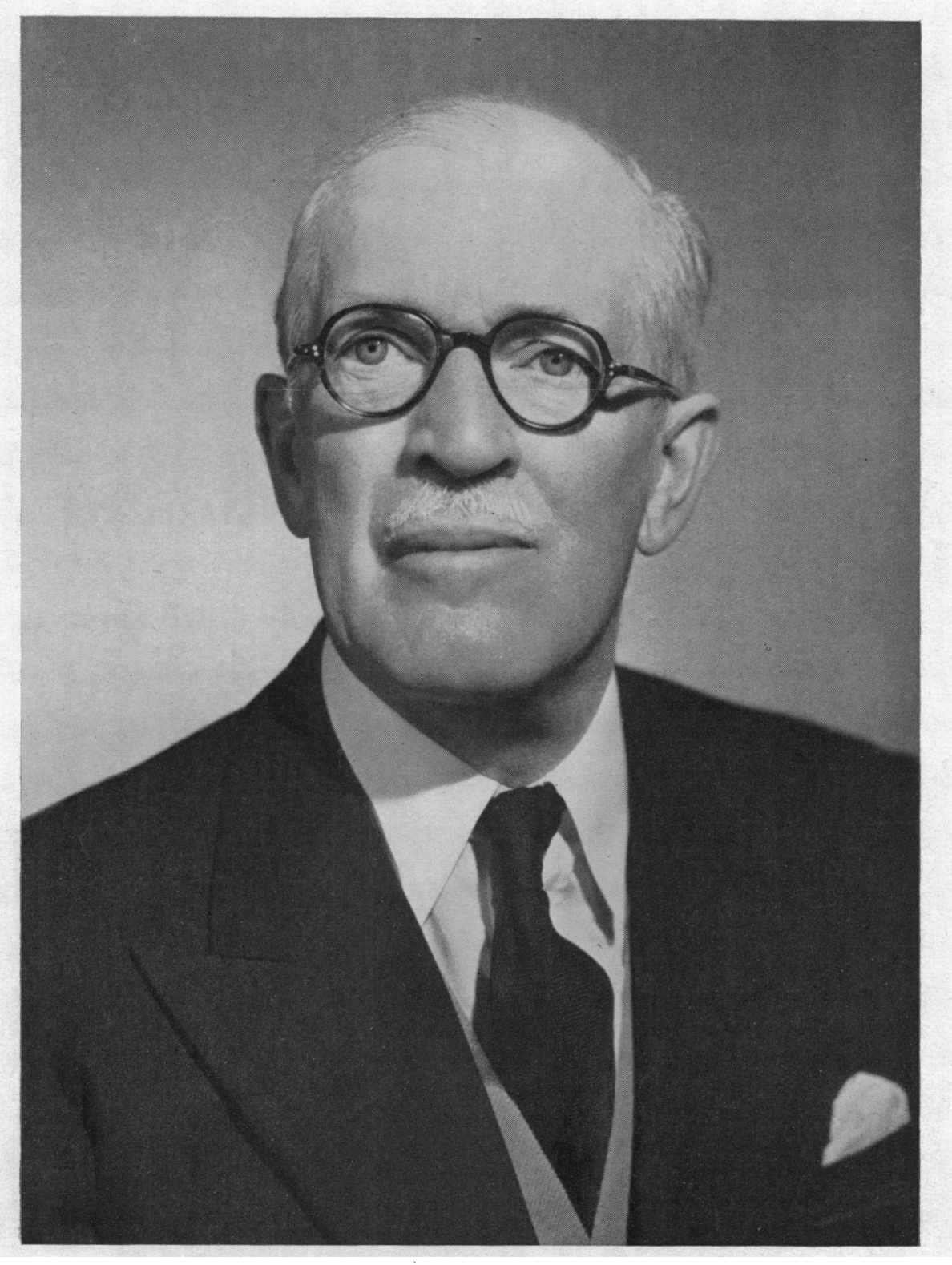

BASILT. PARSONS-SMITH 